\title{
Biological Control as a Tool for Ecosystem Management
}

\author{
David H. Headrick ${ }^{1}$ and Richard D. Goeden \\ Department of Entomology, University of California, Riverside, California 92521
}

\begin{abstract}
Biological control is proposed as a tool useful for ecosystem management and compatible with the goals of often competing interests regarding the restoration and maintenance of ecosystems. We summarize the effects of introduced species on ecosystems in three broad groups: insects, vertebrates, and weeds. We then discuss the role of biological control for each of these groups in the context of ecosystem management and realistic outcomes. Of the three groups, we show that biological control of weeds appears to have the best chance for success in ecosystem management. We provide two case studies to support our ideas and finally discuss future needs and trends including fiscal considerations, cost/benefits associated with biological weed control, and potential funding sources.
\end{abstract}

Key Words: conservation; biological control; weed control; invasive species.

\section{INTRODUCTION}

The proposed increase in the use of biological control agents based on a national commitment to reduce pesticide reliance is under intense scrutiny due to fears that organisms introduced for biological control purposes may have adverse effects on biodiversity and may contribute to the decline of nontarget species ( $\mathrm{Na}$ tional Academy of Sciences, 1987; Simberloff and Stiling, 1996). Most human activities contribute to ecosystem degradation (Primack, 1993; Meffe and Carroll, 1995). The introduction of natural enemies for biological control is the only purposeful human activity that has the power to permanently restore balance to systems that are in ecological dedine due to the destructive effects of adventive pest species and that in so doing allows the damaged ecosystem to regenerate and recover once pest densities are reduced (Debach, 1964; DeBach and Rosen, 1991; Van Driesche and Bellows, 1996).

\footnotetext{
${ }^{1}$ Current address: Crop Science Department, California Polytechnic State University, San Luis Obispo, CA 93407.
}

The debate on biological control agent risk assessment/host specificity pales compared to the whole of humankind's disruptive activities on ecosystem health. The purposeful introduction of a biological control agent and its potential negative impact on the environment into which it is introduced is fundamentally inconsequential compared to the current effects of agriculture, urban development, and resource extraction on the environment (Primack, 1993; M effe and Carroll, 1995). Proponents of limitation of the introduction of natural enemies for biological control do not articulate or demonstrate an appreciation for the subtleties and learned use of taxa employed in modern biological control programs, as evidenced by their broadly based comparisons among highly disparate and unrelated taxonomic groups (Simberloff and Stiling, 1996; Secord and Kareiva, 1996). There is a need for all involved in the debate to develop an appreciation for the biological subtleties, intricacies, and nuances associated with particular insect taxa and the uniqueness of each and every biological control situation (Compere, 1961, 1969; Clausen, 1940, 1978; Hagen and Franz, 1973; Gordh, 1977). If not, the debate over the use of biological control agents in ecosystem management or the enhancement of the discipline as a whole will never make any substantial gains.

Our objectives herein are to support the use of biological control techniques in ecosystem management and to identify the areas where biological control and ecosystem management share mutually compatible research goals. We build our support by defining the effects of adventive organisms on ecosystems, grouped by taxonomic category (insects, weeds, and vertebrates), by scale (ecosystem level and population level), and by temporal realities (biological control can restore past discretions, but cannot protect against future decisions).

Modern humans have heedlessly altered the landscape over long periods of time, bending it to their use, and in doing so have become increasingly distantly removed from nature (Primack, 1993). Collective and accumulated human activities have had large-scale effects on the whole of the biosphere and some of these 
effects have created results that have countered our initial goals. For example, in our effort to attain efficient crop production we have caused many species of insects and weeds to proliferate and become pests, significantly reducing our agricultural productivity (Metcalf, 1994).

The focus of this discussion of the application of biological control in ecosystem management is $\mathrm{N}$ orth America where, because this continent is considered economically advanced, little of the environment has escaped some degree of modification by human activity (Mening, 1990).

\section{GOALS OF ECOSYSTEM MANAGEMENT AND BIOLOGICAL CONTROL}

We group the activities of ecosystem management temporally as (1) present and future and (2) past. E cosystem management activities related to the present and future involve protection. E cosystem management activities related to the past involve restoration and recovery. Recovery applies to populations of endangered or threatened species and the processes by which their decline is arrested or reversed. Restoration applies to ecosystems and the processes by which a site is altered to reestablish a presumed indigenous historical state. E cosystem management takes place typically on a large scale in areas that are considered critical habitat, undeveloped landscapes, wetlands/watersheds, and protected areas including reserves, parks, and other managed areas (Christensen et al., 1996).

Biological control methods cannot be used in ecosystem protection because biological control generally is not a prophylactic procedure, but it can be used for restoration or recovery. Biological control in restoration (of ecosystems) and recovery (of desirable populations) is primarily focused on the introduction of new natural enemies to suppress adventive pest populations (see below) that have adverse effects on an ecosystem or a population. Because ecosystem management programs typically involve areas of substantial size and low per-unit economic worth, biological control demonstrably provides an energy-efficient, safe, longlasting, and cost-effective control option because natural enemies are self-replicating, self-regulating, and often self-dispersing (DeBach, 1964; DeBach and Rosen, 1991; Messenger et al., 1976; Van Driesche and Bellows, 1996).

Ecosystems are complex, dynamic systems that express behavior and are reactive to stimuli. E cosystems have an inherent quality of passive regeneration; they have a degree of resilience (Holling, 1992, 1996). Furthermore, regeneration occurs without human aid; the regeneration of the posteruption landscape of Mount St. Helens is an edifying example (Carson, 1990). Thus, if the goal of ecosystem management is the establishment of an historical state of being, then this may require the passive process of regeneration. A part of management may rely on nonintervention (Thomas, 1996). Restoration of an ecosystem may have as its goal the establishment of a site either as a "productive" (resource extraction, grazing, forestry, etc.) or as a "nonuse" (protected area in which human activity is restricted) state (Heissenbuttel, 1996; Stanford and Poole, 1996). Biological control can be employed in the attainment of either goal.

\section{EFFECTS OF ADVENTIVE SPECIES (IN SECTS, VERTEBRATES, AND WEEDS)}

Rates of acquisition. According to the U.S. Congress Office of Technology Assessment (OTA, 1993) more than 2000 species of plants and invertebrates extant in the United States originated elsewhere. These estimates are tempered by OTA's (1993) characterization of information on adventive species as being widely scattered and often anecdotal and by the observation that the numbers and impacts of harmful adventive species in the United States are chronically underestimated (OTA, 1993).

What is the expectation for the acquisition of adventive species? California acquired ca. 200 new arthropod species from 1955 to 1988 (Dowell and Gill, 1989). There is considerable variation from year to year, but the average over the 33-year period is 6.1 species per year or 1 new species being discovered in California every 60 days. California is on the high end of the scale for N orth America as a whole because of its location on the Pacific rim and the tremendous influx of commerce, tourism, and immigration. Rates of invasion of adventive species are difficult to obtain for the United States as a whole, but Sailer (1983) estimated that 11.0 adventive species per year are discovered in the continental United States.

F or plant species, documentation of rates of acquisition are difficult to obtain. In Canada, adventive plants comprise $28 \%$ of the total flora (Heywood, 1989). The J epson Manual (Hickman, 1993) states that of the 5862 plant species occurring in California, 3423 (59\%) are native, 1416 (24\%) are endemic, and 1023 (17\%) are alien. Since the publication of the J epson Manual, collection records indicate that an additional 21 species of plants new to California have been discovered (Sanders, 1996; Sanders and Boyd, 1996; Ross and Boyd, 1996; Sanders and Koutnik, 1997). Of these, 9 species are consider ed aggressive weeds. Bearing in mind that collections and surveys of plants, like many other aspects of field biology, currently are being conducted on an extremely limited, decreasing scale, further collections would certainly uncover a greater number of adventive species and are worthy of specific, obtainable funding.

Attainment of pest status. We suggest three fates for adventive species: (1) they fail to establish, (2) they 
establish and persist at nonconsequential densities, or (3) they establish and attain consequential densities (=achieve pest status). Williamson and Fitter (1996) have developed the "ten's rule" to help determine the numbers associated with these three fates. Adventive species attain high densities because they are often introduced without their associated natural enemies and they are able to utilize an often abundant resource in an invaded area, thus leading to unchecked population growth (DeBach, 1964; Vitousek, 1986; Van Driesche and Bellows, 1996).

Sailer (1983) calculated that of the 1683 adventive species introduced in North America up to 1983, 14\% were important pests, 37\% were minor pests, 25\% were unimportant economically, and $24 \%$ were beneficial species of insects introduced for biological control. The costs associated with those species that become pests has been estimated at $\$ 3$ billion annually in California alone (Sailer, 1983).

Effects of adventive pests. Most discussions relative to the risks associated with organisms introduced for biological control fail to recognize the overall effects associated with any adventive organism. The effects caused by adventive pests include (1) habitat degradation such as the loss of undisturbed habitat area or fragmentation, monopolization and contamination of resources, altered rates of predation, parasitism, or disease (Primack, 1993; Meffe and Carroll, 1995), and, specific to adventive weeds, habitat fragmentation, changes in water table levels, changes in soil fertility, and altered fire frequency or intensity (Vitousek, 1986, 1992; Van Driesche and Bellows, 1996) and (2) changes in species composition such as the direct and indirect decrease or increase of a population's density, local or widespread extinction of populations or an entire species, and changes in conditions that result in the addition of species to an ecosystem (Huffaker, 1964; Primack, 1993; Meffe and Carroll, 1995; Van Driesche and Bellows, 1996).

These two effects occur at two different scales: habitat degradation is ecosystem level and changes in species composition are population level. Examples of each of these types of effects are provided below. We group adventive species into three taxonomic categories: insects, vertebrates, and plants. Examples for each are provided and discussed, but this is not a comprehensive listing. We do not treat adventive pathogens in this discussion [see McCallum and Dobson (1995) and Federici and Maddox (1996)].

Insects. Adventive insect species that become pests rarely cause ecosystem-level habitat degradation. To do so, phytophagous insects would have to cause substantial, widespread loss of one or more dominant native plant species. For insects with other trophic strategies, e.g., entomophagous species, the outcome of habitat degradation is even less likely.
Adventive phytophagous arthropods are more likely to attack adventive host plant species than indigenous host plant species in the same system (Van Driesche and Bellows, 1996). Adventive plant species occur in most natural systems, and in some cases their numbers can be quite high; e.g., from 3 to $66 \%$ of the flora found on federal lands such as national parks are adventive (Loope, 1992).

Examples of phytophagous insects causing habitat degradation are equivocal, but may include the introduced scales Carulaspis minima (Targioni-Tozzetti) and Insulaspis pallida (Maskell), which virtually exterminated the Bermuda cedar, J uni perus bermudiana L. (Cock, 1985). Also, the hemlock woolly adelgid Adelges tsugae Annand, an adventive insect species, has been killing two species of hemlock in eastern North America, Tsuga canadensis Carriere and Tsuga caroliniana Engelmann. These tree species are an important part of the deciduous tree flora in the eastern United States, particularly along rivers, on north slopes, and in ravines (McClure, 1989; Salon et al., 1996). The introduction of the Lesser European bark beetle, Scolytus multistriatus (Marsham), along with the fungal agent of Dutch elm disease, Ophiostoma ulmi (Schwarz), has caused loss of 46 million native American elms in the upper midwestern and eastern regions of the United States (Wallner, 1996).

Population-level effects of adventive insect species resulting in changes in species composition or loss of species diversity also are rare. However, among phytophagous insects, Huffaker (1964) noted that prolonged outbreaks of the southern pine beetle Dendroctonus frontalis Zimmerman transformed pure stands of pine trees into stands mixed with hardwood species. Recently, the Mexican weevil Metamasius callizona (Chevrolat) was introduced into Florida through commercial trade in bromeliads. The weevil is now causing losses of native and threatened species of bromeliads (Frank and Thomas, 1994).

Population-level effects vary for insects that exhibit other trophic strategies. Adventive ant species can have significant effects on indigenous ant populations; e.g., the Argentine ant Linepithema humile (Mayr), when introduced into South Africa, displaced most of the indigenous ant fauna (Breytenbach, 1986). Similarly, the Crazy ant, Paratrechina fulva (Mayr), was introduced from northern Brazil to northern Colombia in an attempt to suppress poisonous snake populations. The eventual outcome was the disappearance of 36 of 38 species of ants indigenous to the invaded area and 7 other soil-dwelling insect species, 1 snake species, and 3 lizard species (de Polania and Wilches, 1992).

Caution should be used in identifying the damage caused by adventive phytophagous insect species which may increase logarithmically in population density in an invaded area. A consequence of this explosion 
is an increase in the number of hosts plants upon which the introduced insect is found developing. This is especially true of whiteflies (Homoptera: Aleyrodidae). For example, Aleurodicus dugesi i Cockerell is native to Mexico and is found there on a limited number of host plants, mainly Hibiscus rosa-sinensis L. In California, where A. dugesii has invaded and a logarithmic growth phase has been recorded, the number of host plants among different plant families has been as high as 79 recorded species (T. S. Bellows and D. H. Headrick, unpublished data). Once effective biological control agents are in place, the density of A. dugesi i should be reduced and the number of host species upon which it can persist should decrease substantially, as shown with the ash whitefly, Siphoninus phillyreae (Haliday) (Gould et al., 1992a,b).

Vertebrates. Habitat degradation including fragmentation, changes in species composition, and loss of diversity are hallmarks of activity by adventive vertebrate species (Bomford et al., 1995; Primack, 1993; Meffe and Carroll, 1996). Introductions of herbivores such as mice, rabbits, and ungulates have caused extensive damage to agricultural, urban, and natural landscapes in areas recently colonized by Europeans (Singleton, 1989; Myers et al., 1994; CAST, 1996; Edwards et al., 1996). The introduction of cattle has had controversial impacts on native landscapes. For example, cattle grazing has, in some cases, caused changes in species composition which have resulted in an increase in biodiversity (CAST, 1996). This is due to the alteration of a perennial-dominated grassland composed of a few dominant species of grasses to an annualdominated system, and, thus, the number of annual species after the alteration is greater than that in the previous perennial system (Heady and Child, 1994).

Introduced vertebrate predator species have in some cases caused extensive environmental damage, most often in closed habitats such as islands (Chapuis et al., 1994; Meffe and Carroll, 1996). For example, domestic cats, Felis cattus L., introduced either as pets that subsequently become feral or as predators specifically to control exploding rodent populations, ultimately often have adverse effects on avian fauna (van Rensburg et al., 1987). The Brown tree snake, Boiga irregularis Fitzinger, when accidentally introduced into Guam, virtually eliminated the entire native, forest-dwelling avifauna (Savidge, 1987).

Biological control of vertebrates is largely dependent on the introduction of pathogenic organisms (van Rensburg et al., 1987; Tyndale-Biscoe, 1994; Williams et al., 1995; McCallum, 1996; Hoddle, 1999). However, this continues to be a controversial area of biological control research. The premature escape of the calicivirus during testing for its use against the European rabbit (Oryctolagus cuniculus L.) in Australia validated fears of unpredictable movements of pathogens (Anderson,
1995; Lawson, 1995; McCallum, 1996). This example validates the need for improved testing methods when dealing with pathogenic organisms, but should not serve to rescind the use of biological control as a method for vertebrate pest control (Hoddle, 1999).

Weeds. Habitat degradation is common for adventive weeds that become pests because, unlike the case of adventive insects, habitat degradation is a consequence of the proliferation of the adventive weed species and not a result of the decline or loss of a dominant, indigenous species due to the feeding of an adventive phytophagous insect. We believe that this is a significant concept relative to the effects expected from adventive species and one that has been largely ignored in the literature regarding the introduction of organisms for biological control.

There are many examples from the weed literature that illustrate their effects on habitat degradation. Some, however, highlight in particular the role of weed suppression by biological control methods and its benefit for ecosystem management.

The proliferation and dominance of St. J ohn's wort, Hypericum perforatum L., in the Pacific northwest reduced the diversity of grass species there and created significant degradation of grassland-type ecosystems (Crompton et al., 1988). St. J ohn's wort was successfully controlled in the Pacific northwest by the introduction of natural enemies (Holloway, 1948). However, the stability and value of the plant communities that replaced $\mathrm{H}$. perforatum differ among treated areas. In California, the vast areas once dominated by St. J ohn's wort were filled by a dominant, perennial grass, Danthonia californica Bolander, plus annual grasses, legumes, and forbs (Huffaker, 1951; Huffaker and Kennett, 1959). The diversity of the original perennial grassland ecosystem had been restored. In contrast, $\mathrm{H}$. perforatum was replaced by the same introduced forbs and feral grasses that had been dominant before its invasion in northern Idaho (Tisdale, 1976). Many of these introduced species were annual grasses that had replaced the original perennial species due to overgrazing practices and thus did not constitute a stable plant community. After the decline of $\mathrm{H}$. perforatum, subsequent invasions of new and similarly noxious weed species such as yellow starthistle and spotted knapweed occurred (Campbell and McCaffrey, 1991). Restoration of species diversity following widespread reductions in weed populations is expected, but the re sultant species composition is ultimately influenced by other variables and conditions (CAST, 1996).

Several weed species in North America which cause severe habitat degradation and loss of diversity and for which biological control programs are currently ongoing include leafy spurges (E uphorbia spp.) and thistles and knapweeds (Carduus, Centaurea, Cirsium, and SiIybum spp.) (Nechols et al., 1995). These programs are 
economically driven because these weeds reduce forage for cattle and sheep and these and other weed species contain toxins that cause loss of weight or death in livestock.

Examples of biological control of weeds projects based on conservation rather than economics include purple loosestrife, Lythrum salicaria L. (Malecki et al., 1993), and Melaleuca quinquenervia (Cavanilles) Blake (Ewel, 1986; Bodle et al., 1994).

\section{JUSTIFICATION FOR BIOLOGICAL CONTROL IN ECOSYSTEM MANAGEMENT}

Insects. Based on the above, we suggest that there is and will be limited need for biological control of insects relative to ecosystem management. However, when needed, biological control can be an effective solution. Among those insects that are disruptive to the environment, there may be limited opportunities for application, e.g., adelgids lacking parasitoids; in the case of Dutch elm disease, even small populations of the bark beetle can vector the pathogen. Biological control does not strive for eradication and, thus, has limited use in the indirect control of arthropod-vectored plant diseases.

Vertebrates. Pest vertebrates will afford limited application of biological control due to the almost sole reliance on pathogenic organisms. The release of vertebrate pathogens will always be controversial due to the overriding concern for safety (Hoddle, 1999).

Weeds. Biological control of adventive weeds is a useful option with potentially widespread application and long-term benefits. The foll owing case studies support this idea, but also highlight some of the potential problems. The two studies detailed bel ow also share an important quality that is missing from most such research: they are long-term studies that have lasted for decades. Only with such persistence are we able to illustrate how practitioners of biological control will eventually learn from experience and apply the knowledge that they have gained.

\section{CASE STUDIES}

Opuntia spp. The Opuntia cactus biological control program on Santa Cruz I sland off the coast of southern California highlights many of the advantages and restrictions encountered with the use of biological control in environmental conservation, including duration, competing interests, native species issues, and productive versus nonuse lands. The Opuntia spp. were native to the island, but colonized new habitat following overgrazing by cattle. The destruction of rampant populations of the cactus and its continued control by introduced phytophagous insects and effective range management practices have subsequently allowed for, over a 30-year period, the regeneration of the native vegetation (Goeden et al., 1967; Goeden and Ricker, 1980).

Italian and milk thistle. There have been substantial benefits to natural ecosystem and rangeland recovery following the releases of Rhinocyllus conicus into North America for exotic thistle control (Kok and Surles, 1975; Kok, 1998). However, the weevil has had equivocal success in some areas and may be having negative effects on an endangered thistle species (Louda et al., 1997).

Postrelease studies following the introduction of $R$. conicus into southern California for exotic thistle control in the early 1970s showed that the weevil was (1) feeding and developing on nontarget, native thistles (Cirsium spp.) (Goeden and Ricker, 1977, 1978) and (2) largely ineffective at controlling its target thistles, Carduus pycnocephalus and Silybum marianum, due to phenol ogical, or seasonal, asynchrony with its target host species (Goeden and Ricker, 1985). The first issue was not an unexpected outcome. At the time, biological control agents were chosen with a broader host range than just the target species. The rationale was that alternate hosts provide a greater chance of survival and spread of the biological control agent even if the target species became scarce or locally extinct for even short periods of time (Bellows and Headrick, 1999).

Recently, a critic of biological control methodology attempted to make R. conicus a pariah (Strong, 1997), citing the above issues as representing an "ecological time-bomb." Studies in 1998-1999 of R. conicus development and reproduction on native Cirsium spp. in its area of introduction 3 decades earlier have shown that the weevil also is seasonally asynchronous with native thistle species, and plant reproduction remains unaffected (Oishi and Headrick, 2001, unpublished data).

\section{FISCAL CONSIDERATIONS}

What price do we place on a pristine environment? What value can be placed on a natural habitat? The economics of environmental conservation are difficult and controversial simply because there is no arguably intuitive, adequate economic value that can be placed on a desirable, undisturbed or nonuse landscape. Value or worth, in the form of a conceptual valuation model (Pearce and Moran, 1994), for some ecosystems such as wetlands or forests is derived by the listing of their attributes, which provide an estimate of their outputs, which are then transformed into potential economic functions, which finally lead to economic values (Thomas et al., 1979; Leitch et al., 1984; Pearce and Moran, 1994). Thus, the wetland is not valued directly, but as the end product of how the ecosystem affects societal well-being (e.g., as a protective barrier from flooding). However, these data are difficult to obtain and the value estimated for one parcel of wetland may not be 
the same even for an adjacent parcel, much less for one in a another region (CAST, 1994).

Cost/ benefit analysis. Restoration programs associated with nonuse areas as defined earlier are not economically driven (Pearce and Moran, 1994). Therefore, cost/benefit analyses are difficult to develop for such projects because the "benefit" part of the equation cannot be adequately quantified (Greer, 1995; CrutwellMcFayden, 1995).

Nonuse landscapes differ from those landscapes that play host to a number of human activities and thus are afforded tangible values (Pearce and Moran, 1994). Grassland ecosystems are valued for products derived from their use, e.g., cattle (CAST, 1996). Restoration programs for damaged grasslands are aimed at returning them to a productive state rather than to a nonuse state, and so the costs of a control method can be weighed against the economic losses derived without its use (Greer, 1995). For example, the successful biological control of the St. J ohn's wort was shown to have saved the cattle industry over \$8 million in a 6-year period as a result of increased land values and cessation of herbicidal treatments and another $\$ 2$ million from cattle weight gain (in late 1950s dollars) (DeBach, 1964). The successful biological control of tansy ragwort in Oregon saved the cattle industry between $\$ 2.4$ and $\$ 4.8$ million annually (in 1980s dollars), a potential cost/benefit ratio of $1: 10,000$ or more (AliNiazee, 1995).

Despite the complications associated with economic valuation for either nonuse or restored productive lands, biological control can function well in both settings to provide sound economic benefits compared to other control technologies or the absence of controls (Harris, 1988).

Funding sources. Funding biological control in ecosystem management programs is potentially difficult (Baker, 1996). The majority of biological control research in the United States takes place under the aegises of the USDA Agricultural Research Service, state Departments of Agriculture, or various universities. F unding for USDA programs are federally administered and USDA scientists may al so compete for state or commodity-related funding. Funding for programs at universities are derived from many sources, most competitive. The major issue concerning biological control research is time. Biological control programs are long-term by nature, with entomophagous programs averaging 3-5 years and weed programs averaging 10-12 years and sometimes taking 20 years or more (Harris, 1993). The average duration of a research grant is 2-3 years. This disparity causes difficulties in obtaining continued support for the duration of a program.

One source that has in many instances provided the means to bridge these funding cycles is commodity- derived research funds. Sawyer (1996) details how important the citrus commodity-University of California tie is and how important the role that the citrus industry has played in the development of biological control as a scientific discipline is. For lands that are to be set aside for nonuse, the interactions and mutual support system so long valued by biological control researchers is absent. Ultimately, support will have to become a national or regional issue and financial support-especially long-duration support-will have to be derived from federal, regional, or state consortia of universities and agencies (Schroeder and Müller-Schärer, 1995; Baker, 1996; Wallner, 1996).

\section{RESEARCH OBJECTIVES}

The use of biological control methods against adventive weeds in ecosystem management will require an agreed upon context for target determination (Wapshere, 1973, 1974; Schroeder and Müller-Schärer, 1995; Malecki et al., 1993). Huffaker (1964) identified several conflicts of interest inherent in biological control of weeds. At the root of most conflicts is the "economic position of the target weed." A plant species that is considered a weed in one context may serve a useful purpose in another context. Thus, target determination will ultimately have to weigh the relative value of a weed in all situations. Once these variable views of a weed's relative worth have been determined, its worth versus harm will have to be compared. The balance between human needs and environmental responsibility will always be difficult to tease apart and every situation will be unique.

Other issues related to target determination include competing interests based on where the biological control program is to take place. An ecosystem may cross several geo- or sociopolitical boundaries. Biological control agents do not recognize these boundaries. If affected lands are owned by different agencies that do not share a common philosophy or goal there will be conflicts. F or example, federal parks abide by a multiple-use philosophy and this may conflict with the nonuse philosophy of a private organization (Christensen et al., 1996; Wallner, 1996).

Finally, safety is al ways a concern for those involved in biological control research. The effects on nontarget species will have to be evaluated in regard to the release of phytophagous species in biological control programs (Wapshere, 1974; McEvoy, 1996).

\section{ACKNO WLEDGMENTS}

We thank Mark Hoddle for providing literature sources on several topics and for helpful comments on early drafts of the manuscript. We thank two anonymous reviewers for their excellent critique and thought-provoking commentary. We also thank Tom Bellows and Roy Van Driesche for helpful discussions in regard to the use of biological control in ecosystem management. 


\section{REFERENCES}

AliNiazee, M. T. 1995. The economic, environmental, and sociopolitical impact of biological control. In "Biological Control in the Western United States" (J . R. Nechols, L. A. Andres, J. A. Beardsley, R. D. Goeden, and C. J . J ackson, Eds.), pp. 47-56. Univ. Calif. Div. Nat. Agric. Resources, Publ. 3361, Berkeley.

Anderson, L. 1995. Runaway rabbit virus kills millions. New Sci. 148, 4.

Baker, D. J . 1996. What do ecosystem management and the current budget mean for federally supported environmental research? Ecol. Appl. 6, 712-714.

Bellows, T. S., and Headrick, D. H. 1999. Arthropods and vertebrates in biological control of plants. In "Handbook of Biological Control" (T. S. Bellows and T. W. Fischer, Eds.), pp. 505-516. Academic Press, San Diego.

Bodle, M. J ., Ferreter, A. P., and Thayer, D. D. 1994. The biology, distribution, and ecological consequences of Melaleuca quinquenervia in the Everglades. In "Everglades: The Ecology and I ts Restoration" (S. M. Davis and J. C. Ogden, Eds.), pp. 341-356. St. Lucie Press, Delray Beach, FL.

Bomford, M., Newsome A., and O'Brien, P. 1995. Solutions to feral animal problems: Ecological and economic principles. In "Conserving Biodiversity: Threats and Solutions" (R. Bradstock, T. Auld, D. Keith, R. Kingston, D. Lunnet, and D. Siverston, Eds.). Beatty and Sons, Surrey, UK.

Breytenbach, G. J . 1986. Impacts of alien organisms on terrestrial communities with emphasis on communities of the southwestern Cape. In "The E cology and Management of Biological Invasions in Southern Africa: Proceedings of the National Synthesis Symposium on the Ecology of Biological Invasions" (I. A. W. Macdonald, F. J . Kruger, and A. A. Ferrar, Eds.), pp. 229-238. Oxford Univ. Press, Cape Town, South Africa.

Campbell, C. L., and McCaffrey, J . P. 1991. Population trends, seasonal phenology, and impact of Chrysolina quadrigemina, C. hyperici (Coleoptera: Chrysomelidae), and Agrilus hyperici (Coleoptera: Buprestidae) associated with Hypericum perforatum in northern I daho. Environ. Entomol. 20, 303-315.

Carson, R. 1990. "Mount St. Helens." Sasquatch Books, Seattle.

Chapuis, J . L., Bousses, P., and Barnaud, G. 1994. Alien mammals, impact and management in the French subantarctic islands. Biol. Conserv. 67, 97-104.

Christensen, N. L., Bartuska, A. M., Brown, J. H., Carpenter, S., D'Antonio, C., Francis, R., Franklin, J . F., MacMahon, J . A., Noss, R. F., Parsons, D. J ., Peterson, C. H., Turner, M. G., and Woodmansee, R. G. 1996. The report of the E cological Society of America committee on the scientific basis for ecosystem management. Ecol . Appl. 6, 665- 691.

Clausen, C. P. 1940. "Entomophagous Insects." McGraw-Hill, New York.

Clausen, C. P. 1978. "Introduced Parasites and Predators of Arthropod Pests and Weeds: A World Review." USDA/ARS Agricultural Handbook 480, Washington, DC.

Cock, M. J . W. 1985. "A Review of Biological Control of Pests in the Commonwealth Caribbean and Bermuda up to 1982." Tech. Commun. 9, Commonwealth Institute of Biological Control, Commonwealth Agricultural Bureaux, Farnham Royal, UK.

Compere, H. 1961. The red scale and its insect enemies. Hilgardia 31, 173-278.

Compere, H. 1969. Changing trends and objectives in biological control. Proc. 1st Int. Citrus Symp. 2, 755-764.

Council for Agricultural Science and Technology (CAST). 1994. "Wetland Policy Issues." CAST, Ames, IA.

Council for Agricultural Science and Technology (CAST). 1996. "Grazing on Public Lands." CAST, Ames IA.
Crompton, C. W., Hall, I. V., J ensen, K. I. N., and Hilderbrand, P. D. 1988. The biology of Canadian Weeds. 83. Hypericum perforatum L. Can. J . Plant Sci. 68, 149-162.

Crutwell-McFadyen, R. E. 1995. Biological control in protected natural areas. In "Proceedings of the 8th I nternational Symposium on Biological Control of Weeds, Canterbury, New Zealand" (E. S. Delfosse and R. R. Scott, Eds.), p. 19. DSIR/CSIRO, Melbourne, Australia.

DeBach, P. (Ed.). 1964. "Biological Control of Insect Pests and Weeds." Reinhold, New York.

DeBach, P., and Rosen, D. 1991. "Biological Control by Natural Enemies." Cambridge Univ. Press, Cambridge, UK.

de Polania, I. Z., and Wilches, O. M. 1992. Impacto ecologico de la hormiga loca, Paratrechina fulva (Mayr), en el municipio de Cimitarra (Santander). Rev. Colombiana Entomol. 18, 14-22.

Dowell, R. V., and Gill, R. 1989. Exotic invertebrates and their effects in California. Pan-Pac. Entomol. 65, 132-145.

Edwards, G. P., Croft, D. B., and Dawson, T. J . 1996. Competition between red kangaroos (Macropus rufus) and sheep (Ovis aries) in the arid rangelands of Australia. Aust. J . Ecol. 21, 165-172.

Ewel, J . J . 1986. Invasibility: Lesson from south Florida. In "E cology of Biological Invasions of North America and Hawaii" (H. A. Mooney and J . A. Drake, Eds.), pp. 214-231. Springer-Verlag, New York.

Federici, B. A., and Maddox, J . V. 1996. Host specificity in microbeinsect interactions. BioScience 46, 410- 421.

Frank, J . H., and Thomas, M. C. 1994. Metamasius callizona (Chevrolat) (Coleoptera: Curculionidae), an immigrant pest, destroys bromeliads in Florida. Can. Entomol. 126, 673- 682.

Goeden, R. D., Fleschner, C. A., and Ricker, D. W. 1967. Biological control of prickly pear cacti on Santa Cruz Island, California. Hilgardia 38, 579-606.

Goeden, R. D., and Ricker, D. W. 1977. Establishment of Rhinocyllus conicus (Col.: Curculionidae) on milk thistle in southern California. Weed Sci. 25, 288-292.

Goeden, R. D., and Ricker, D. W. 1978. Establishment of Rhinocyllus conicus (Col.: Curculionidae) on Italian thistle in southern California. Ann. Entomol. Soc. Am. 7, 787-789.

Goeden, R. D., and Ricker, D. W. 1980. Santa Cruz I sland-revisited. Sequential photography records the causation, rates of progress, and lasting benefits of successful biological weed control. Proc. V Int. Symp. Biol. Control Weeds, Brisbane, Australia, pp. 355-365.

Goeden, R. D., and Ricker, D. W. 1985. Seasonal asynchrony of Italian thistle, Carduus pycnocephalus, and the weevil, RhinocylIus conicus (Coleoptera: Curculionidae), introduced for biological control in southern California. Environ. Entomol. 14, 433- 436.

Gordh, G. 1977. Biosystematics of natural enemies. In "Biological Control by Augmentation" (R. L. Ridgeway and S. B. Vinson, Eds.), pp. 125-150. Plenum, New York.

Gould, J. R., Bellows, T. S., and Paine, T. D. 1992a. Population dynamics of Siphoninus phillyreae in California in the presence and absence of a parasitoid, Encarsia partenopea. Ecol. Entomol. 17, 27-134.

Gould, J . R., Bellows, T. S., and Paine, T. D. 1992b. Evaluation of biological control of Siphoninus phillyreae (Haliday) by the parasitoid Encarsia partenopea (Walker), using life table analysis. Biol. Control 2, 257-265.

Greer, G. 1995. Economics of the biological control of weeds. In "Proceedings of the 8th International Symposium on Biological Control of Weeds, Canterbury, New Zealand" (E. S. Delfosse and R. R. Scott, Eds.), pp. 177-184. DSIR/CSIRO, Melbourne, Australia. 
Hagen, K. S., and Franz. J . M. 1973. A history of biological control. In "History of Entomology" (R. Smith and T. C. Mittler, Eds.), pp. 433- 476. Annual Review, Palo Alto, CA.

Harris, P. 1988. Environmental impact of weed-control of insects. BioScience 38, 542-548.

Harris, P. 1993. Effects, constraints and the future of weed biocontrol. Agric. Ecosyst. Environ. 46, 289-303.

Heady, H. F., and Child, R. D. 1994. "Rangeland Ecology and Management." Westview Press, Boulder, CO.

Heissenbuttel, A. E. 1996. Ecosystem management-Principles of practical application. Ecol. Appl. 6, 730-732.

Heywood, V. H. 1989. Patterns, extents and modes of invasions by terrestrial plants. In "Biological Invasions: A Global Perspective" (J . A. Drake et al., Eds.), pp. 31-60. Wiley, New York.

Hickman, J. C. (Ed.). 1993. “The J epson Manual: Higher Plants of California." Univ. of California Press, Berkeley.

Hoddle, M. S. 1999. Biological control of vertebrate pests. In "Handbook of Biological Control" (T. S. Bellows and T. W. Fischer, (Eds.), pp. 955-974. Academic Press, San Diego.

Holling, C. S. 1992. Cross-scale morphology, geometry and dynamics of ecosystems. Ecol. Monogr. 62, 447-502.

Holling, C. S. 1996. Surprise for science, resilience for ecosystems, and incentives for people. Ecol. Appl. 6, 733-735.

Holloway, J . K. 1948. Biological control of Klamath weed: Progress report. J . Econ. Entomol. 41, 56-57.

Huffaker, C. B. 1951. The return of native perennial bunchgrass following the removal of Klamath weed (Hypericum perforatum L.) by imported beetles. Ecology 32, 443- 458.

Huffaker, C. B. 1964. Fundamentals of biological weed control. In "Biological Control of Insect Pest and Weeds" (P. DeBach, Ed.), pp. 631-670. Reinhold, New York.

Huffaker, C. B., and Kennett. C. E. 1959. A ten-year study of vegetational changes associated with biological control of Klamath weed. J . Range Manag. 12, 69-82.

Kok, L. T., and Surles, W. W. 1975. Successful biocontrol of Musk thistle by an introduced weevil, Rhinocyllus conicus. Environ. Entomol. 4, 1025-1027.

Kok, L. T. 1998. Rhinocyllus conicus. Available at: http://www. nysaes.cornell.edu/ent/biocontrol/weedfeeders/rhinocyllus_c.html.

Lawson, M. 1995. Rabbit virus threatens ecology after leaping the fence. Nature 378, 531.

Leitch, J . A., Easter, K. W., and Nelson, W. C. 1984. A proposed framework for developing a multidisciplinary wetlands valuation model. Environ. Prot. 6, 117-124.

Loope, L. L. 1992. An overview of problems with introduced plant species in national parks and biosphere reserves in the United States. In "Alien Plant Invasions in Native E cosystems of Hawaii: Management and Research" (C. P. Stone, C. W. Smith, and J . T. Tunison, Eds.), pp. 3-28. Univ. of Hawaii Press, Honolulu.

Louda, S. M., Kerdall, D., Conner, J., and Simberloff, D. 1997. Ecological effects of an insect introduced for biological control of weeds. Science 277, 1088-1090.

Malecki, R. A., Blossey, B., Hight, S. D., Schroeder, D., Kok, L. T., and Coulson, J. R. 1993. Biological control of purple loosestrife. BioScience 43, 680-686.

McCallum, H. 1996. Immunocontraception for wildlife population control. Trends Ecol. Evol. 11, 491- 493.

McCallum, H., and Dobson, A. 1995. Detecting disease and parasite threats to endangered species and ecosystems. Trends Ecol. Evol. 10, 190-194.

McClure, M. S. 1989. Evidence of a polymorphic life cycle in the hemlock woolly adelgid, Adelges tsugae (Homoptera: Adelgidae). Ann. Entomol. Soc. Am. 82, 50-54.

McEvoy, P. 1996. Host specificity and biological pest control. BioScience 46, 401- 405.

Meffe, G. K., and Carroll, C. R. 1995. "Principles of Conservation Biology." Sinauer, Sunderland, MA.

Mening, D. W. 1990. Forward. In "The making of the American Landscape" (M. P. Cozen, Ed.), pp. 1-8. Unwin Hyman, Boston.

Messenger, P. S., Wilson, F., and Whitten, M. J . 1976. Variation, fitness, and adaptability of natural enemies. In "Theory and Practice of Biological Control" (C. B. Huffaker and P. S. Messenger, Eds.), pp. 209-231. Academic Press, New York.

Metcalf, R. 1994. The need for research on exotic pests in California. In "The Mediterranean Fruit Fly in California: Defining Critical Research" (J. G. Morse, R. L. Metcalf, J. R. Carey, and R. V. Dowell, Eds.), pp. 5-40. Univ. of California Press, Berkeley.

Myers, K., Parer, I., Wood, D. H., and Cooke, B. D. 1994. The rabbit in Australia. In "The European Rabbit: The History and Biology of a Successful Colonizer" (H. V. Thompson and C. King, Eds.). Oxford Univ. Press, London.

National Academy of Sciences. 1987. “Research Briefings 1987: Report of the Research Briefing Panel on Biological Control in Managed Ecosystems." Natl. Acad. Sci., Washington, DC.

Nechols, J. R., Andres, L. A., Beardsley, J . A., Goeden, R. D., and J ackson, G. C. (Eds.). 1995. "Biological Control in the Western United States." Univ. Calif. Div. Nat. Agric. Resources, Publ. 3361, Berkeley.

Office of Technological Assessment (OTA). 1993. "Harmful Non-indigenous Species in the United States." OTA-F-565, U.S. Govt. Printing Office, Washington, DC.

Oishi, K., and Headrick, D. H. 2001. Ecological effects on non-target thistle species by the introduced weevil, Rhinocyllus conicus in southern California.

Pearce, D., and Moran, D. 1994. "The Economic Value of Biodiversity." IUCN, Earthscan Publ., London.

Primack, R. B. 1993. "Essentials of Conservation Biology." Sinauer, Sunderland, MA.

Ross, T. S., and Boyd, S. 1996. Noteworthy Collections: California. Madrono 43, 334-338.

Sailer, R. 1983. History of insect introductions. In "Exotic Plant Pests and North American Agriculture" (C. L. Wilson and C. L. Graham, Eds.), pp. 15-38. Academic Press, New York.

Salon, S. M., Tigner, T. C., and Reardon, R. C. 1996. "Proceedings of the First Hemlock Woolly Adelgid Review. Oct. 12, 1995, CharIottesville, VA." USDA, Forest Service FHTET 96-10.

Sanders, A. C. 1996. Noteworthy Collections: California. Madrono 43, 523-524.

Sanders, A. C., and Boyd, S. 1996. Noteworthy Collections: California. Madrono 43, 524-532.

Sanders, A. C., and Koutnik, D. 1997. Noteworthy Collections: California. Madrono 44, 17-18.

Savidge, J. A. 1987. Extinction of an island forest avifauna by an introduced snake. Ecology 68, 660-668.

Sawyer, R. 1996. “To Make a Spotless Orange." I owa State Univ. Press, Ames.

Schroeder, D., and Muller-Scharer, H. 1995. Biological control of weeds and its prospectives in Europe. Med. Fac. Landbouww. Univ. Gent. 60(2a), 117-124.

Secord, D., and Kareiva, P. 1996. Perils and pitfalls in the host specificity paradigm. BioScience 46, 448- 453. 
Simberloff, D., and Stiling, P. 1996. Risks of species introduced for biological control. Biol. Conserv. 78, 185-192.

Singleton, G. R. 1989. Population dynamics of an outbreak of house mice (Mus domesticus) in the mallee wheatlands of AustraliaHypothesis of plague formation. J . Zool. 219, 495-515.

Stanford, J. A., and Poole, G. C. 1996. A protocol for ecosystem management. Ecol. Appl. 6, 741-744.

Strong, D. R. 1997. Fear no weevil? Science 277, 1087.

Thomas, J. W. 1996. Forest Service perspective on ecosystem management. Ecol. Appl. 6, 703-705.

Thomas, M. B., Liu, and Randall, A. 1979. "Economic Aspects of Wildlife Habitat and Wetlands, Midwest." Res. Inst. U.S. Water Resources Council, Kansas City, MO.

Tisdale, E. W. 1976. Vegetational responses following biological control of Hypericum perforatum in I daho. Northwest Sci. 50, 61-75.

Tyndale-Biscoe, H. 1994. The CRC for biological control of vertebrate pest populations: Fertility control of wildlife for conservation. Pac. Conserv. Biol. 1, 160-162.

Van Driesche, R. G., and Bellows, T. S. 1996. "Biological Control." Chapman \& Hall, New York.

van Rensburg, P. J . J ., Skinner, J . D., and van Aarde, R. J . 1987.
Effects of feline panleucopaenia on the population characteristics of feral cats on Marion Island. J . Appl. Ecol. 24, 63-73.

Vitousek, P. M. 1986. Biological invasions and ecosystem properties: Can species make a difference? In "E cology of Biological I nvasions of North America and Hawaii" (H. A. Mooney and J. A. Drake, Eds.), pp. 163-176. Springer-Verlag, New York.

Vitousek, P. M. 1992. Effects of alien plants on native ecosystems. In "Alien Plant Invasions in Native Ecosystems of Hawaii: Management and Research" (C. P. Stone, C. W. Smith, and J . T. Tunison, Eds.), pp. 29-41. Univ. of Hawaii Press, Honolulu.

Wallner, W. E. 1996. Invasive pests ('biological pollutants') and US forests: Whose problem, who pays? EPPO Bull. 26, 167-180.

Wapshere, A. J . 1973. A comparison of strategies for screening biological control organisms for weeds. Proc. 2nd Int. Symp. Biol. Control Weeds, Rome, Italy, pp. 95-102.

Wapshere, A. J . 1974. A strategy for evaluating the safety of organisms for biological control of weeds. Ann. Appl. Biol. 77, 201-211.

Williams, C. K., Parer, I., Coman, B. J ., Burley, J ., and Braysher, M. L. 1995. "Managing Vertebrate Pests: Rabbits." Bur. Resource Sci. CSIRO Div. Wildlife Ecol., AGPS, Canberra, Australia.

Williamson, M., and Fitter. A. (1996). The varying success of invaders. Ecology 77, 1661-1666. 